\section{Mitra PGMI:}

Jurnal Kependidikan MI
Mitra PGMI: Jurnal Kependidikan MI

ISSN: 2443-0021 E-ISSN: 2716-4136

https://ejournal.stai-tbh.ac.id/index.php/mitra-pgmi

\title{
Penerapan Model Cooperative Learning Tipe Probing Prompting untuk Meningkatkan Hasil Belajar Kognitif Siswa Mata Pelajaran Fiqih
}

Anas Salahudin ${ }^{1}$, Hariman Surya Siregar ${ }^{2}$, Annisa Nur'azizah ${ }^{3}$

1,2,3 UIN Sunan Gunung Djati, Bandung, Jawa Barat, Indonesia

\begin{abstract}
:
Learning Fiqh in class IV MI Hayatul Islam Cileat was monotonous which affected to lower cognitive learning outcomes. The purpose of this study was to determine whether the Probing Prompting type of Cooperative Learning can improve students' learning outcomes. This research was Classroom Action Research. The results of the mean score before using Probing Prompting was 57.72. In the first cycle, the teacher's activity was $79.99 \%$ while the second cycle was $89.99 \%$. The students' activities in cycle I $79.99 \%$, cycle II $89.99 \%$. Student cognitive learning outcomes after using the Cooperative Learning model type Probing Prompting Learning cycle I 70.34 cycle II 82.27. The accomplishment in Cycle I 54.54\%, Cycle II 95.45\%. The study concluded that the Cooperative Learning type Probing Prompting model could improve student cognitive learning outcomes in fiqh subjects.
\end{abstract}

Keywords: Probing Prompting, cognitive, learning outcomes, Fiqh

\begin{abstract}
Abstrak:
Pembelajaran di kelas IV MI Hayatul Islam Cileat pada mata pelajaran Fiqih dalam proses kegiatan belajar mengajarnya monoton yang mengakibatkan siswa memiliki hasil belajar kognitif yang rendah. Tujuan penelitian ini untuk mengetahui apakah model Cooperative Learning tipe Probing Prompting dapat meningkatkan hasil belajar siswa. Penelitian ini merupakan Penelitian Tindakan Kelas. Hasil yang diperoleh sebelum menggunakan Probing Prompting Learning diperoleh rata-rata 57,72. Pada siklus I keterlaksanaan aktivitas guru rata-rata 79,99\% sedangkan siklus II 89,99\%. Keterlaksanaan aktivitas siswa siklus I 79,99\% siklus II 89,99\%. Hasil belajar kognitif siswa setelah menggunakan model Cooperative Learning tipe Probing Prompting Learning siklus I 70,34 siklus II 82,27. Adapun persentase ketuntasan belajar siklus I 54,54\%, siklus II 95,45\%. Maka kesimpulannya model Cooperative Learning tipe Probing Prompting dapat meningkatkan hasil belajar kognitif siswa pada mata pelajaran fiqih.
\end{abstract}

Kata Kunci: Probing Prompting, kognitif, hasil belajar, Fiqh

\section{Cara mensitasi artikel ini:}

Salahudin, A., Siregar, H. S., \& Nurazizah, A. (2021). Penerapan Model Cooperative Learning tipe Probing Prompting untuk meningkatkan hasil belajar kognitif siswa mata pelajaran Fiqih. Mitra PGMI: Jurnal Kependidikan MI, 7(1), 25-39. https://doi.org/10.46963/mpgmi.v7i1.164.

\section{INFORMASI ARTIKEL}

*Corresponding author: annisa.nurazizah0401@gmail.com DOI: https://doi.org/10.46963/mpgmi.v7i1.164

\section{Histori Artikel:}

$\begin{array}{ll}\text { Diterima } & : 14 / 08 / 2020 \\ \text { Direvisi } & : 22 / 12 / 2020 \\ \text { Diterbitkan } & : 25 / 01 / 2021\end{array}$

\section{PENDAHULUAN}

Pendidikan sangat penting dalam kehidupan dan tidak dapat dipisahkan dari kehidupan manusia. Pendidikan pada dasarnya merupakan proses untuk membantu manusia dalam mengembangkan potensi dirinya sehingga mampu menghadapi setiap perubahan yang terjadi dalam kehidupan. Pendidikan perlu mendapatkan perhatian dan penanganan baik oleh pemerintah, masyarakat maupun keluarga.

Pendidikan menurut Undang-Undang RI No. 20 Tahun 2003 Bab I Pasal 1 tentang Sistem Pendidikan Nasional yang menyatakan bahwa: Pendidikan adalah usaha sadar dan 
terencana untuk mewujudkan suasana belajar dan proses pembelajaran agar peserta didik secara aktif mampu mengembangkan potensi dirinya untuk memiliki kekuatan spiritual keagamaan, pengendalian diri, kepribadian, kecerdasan, akhlak mulia, serta keterampilan yang diperlukan dirinya, masyarakat, bangsa dan Negara.

Pada hakikatnya pendidikan dapat dilakukan dengan berbagai cara baik secara formal maupun informal. Pendidikan formal ditempuh oleh manusia melalui lembaga pendidikan yang disebut dengan sekolah. Sekolah sebagai salah satu lembaga pendidikan yang membantu mengembangkan potensi yang dimiliki peserta didik melalui proses belajar mengajar, fasilitas, sarana dan prasarana, media, sumber belajar dan tenaga kependidikan merupakan fasilitator yang membantu, mendorong dan membimbing peserta didik dalam pembelajaran guna memperoleh keberhasilan dalam belajar.

Dalam memperoleh tujuan pendidikan, maka salah satu bidang yang harus dipelajari oleh siswa di Madrasah Ibtidaiyah adalah Pendidikan Agama Islam yang bertujuan untuk membentuk siswa menjadi manusia yang beriman dan bertakwa kepada Tuhan Yang Maha Esa. Pendidikan Agama Islam di Madrasah Ibtidaiyah salah satunya adalah Fiqih. Fiqih menekankan pada kemampuan cara melaksanakan ibadah dan muamalah yang baik dan benar.

Disadari atau tidak bahwa dalam belajar seseorang bukan hanya diam dan mendengarkan tetapi harus ada perhatian yang lebih, baik pada dirinya sebagai seorang yang sedang belajar, ilmu yang sedang dicari, tujuan mempelajari ilmu itu, dan lingkungan sehingga akan menghasilkan perubahan yang menjadi tujuannya. Karena dalam belajar bukan aspek kognitif saja yang berubah tetapi aspek afektif dan psikomotor pun harus ada perubahan.

Hasil belajar merupakan hasil dari suatu interaksi tindak belajar dan tindak mengajar. Hasil belajar adalah kemampuan-kemampuan yang dimiliki siswa setalah menerima pengalaman belajarnya. Hasil belajar dapat dilihat melalui kegiatan evaluasi yang bertujuan untuk mendapatkan data pembuktian yang akan menunjukkan tingkat kemampuan siswa dalam mencapai tujuan pembelajaran. Kesuksesan terhadap hasil belajar siswa merupakan tujuan akhir yang harus dicapai oleh semua pihak dalam kegiatan pembelajaran. Merujuk pada hal tersebut, pembelajaran ilmu Fiqih merupakan bagian dari materi pelajaran yang dipelajari siswa di MI. Adapun ruang lingkup dalam pembelajaran ilmu Fiqih diantaranya: (1) Ubudiyah (ibadah), (2) Jinayat (hukuman), (3) Munakahat (pernikahan), dan (4) Muamalat (perusahaan).

Tujuan pembelajaran Fiqih agar siswa mengerti tentang bagaimana tata cara/praktik beribadah yang baik dan benar sesuai dengan aturan yang telah ditentukan. Berhasil atau tidaknya proses belajar mengajar mata pelajaran Fiqih bergantung pada faktor-faktor pendidikan yaitu siswa, guru, tujuan, model pembelajaran, media pembelajaran serta lingkungannya. Guru merupakan salah satu sumber pendidikan dan pelaku pendidikan. Penggunaan berbagai model dalam proses belajar mengajar yang menyesuaikan kondisi dan kebutuhan siswa. Tentu saja hal tersebut sangat menentukan terhadap keberhasilan 
proses pembelajaran. Untuk melancarkan kegiatan pembelajaran, seorang guru harus mampu memilih model pembelajaran yang sesuai dengan materi pembelajaran. Agar dalam proses pembelajaran siswa terlibat langsung dan pembelajaran terlaksana dengan baik serta mendapatkan hasil yang optimal. Guru hanya sebagai fasilitator untuk siswa dikelas, guru juga harus menggunakan model pembelajaran yang tepat agar informasi yang disampaikan kepada siswa menjadi relevan, salah satunya dengan menggunakan model Cooperative Learningtipe Probing Prompting Learning.

Lie (2002) menyebut Cooperative Learning dengan istilah pembelajaran gotongroyong, yaitu sistem pembelajaran yang memberi kesempatan kepada peserta didik untuk bekerja sama dengan siswa lain dalam tugas-tugas yang terstruktur. Lebih jauh dikatakan, cooperative learning hanya berjalan kalau sudah terbentuk suatu kelompok atau suatu tim yang di dalamnya siswa bekerja secara terarah untuk mencapai tujuan yang sudah ditentukan dengan jumlah anggota kelompok pada umumnya terdiri dari 4-6 orang (Lie, 2002).

Tujuan utama Cooperative Learning dalam penerapan model belajar mengajar adalah agar peserta didik dapat belajar secara berkelompok bersama teman-temannya dengan cara saling menghargai pendapat dan memberikan kesempatan kepada orang lain untuk mengemukakan gagasannya dengan menyampaikan pendapat mereka secara berkelompok (Isjono, 2013).

Model probing promptinglearning adalah pembelajaran dengan cara guru menyajikan serangkaian pertanyaan yang sifatnya menuntun dan menggali sehingga terjadi proses berpikir yang mengaitkan pengetahuan dan pengalaman siswa dengan pengetahuan baru yang sedang di pelajari. Selanjutnya, siswa mengonstruksi konsep, prinsip dan aturan menjadi pengetahuan baru. Dengan demikian, pengetahuan baru tidak diberitahukan. Dengan pembelajaran ini, proses tanya jawab dilakukan dengan menunjuk siswa secara acak sehingga setiap siswa mau tidak mau harus berpartisipasi aktif, siswa tidak bisa menghindar dari proses pembelajaran, setiap saat ia bisa dilibatkan dalam proses tanya jawab (Shoimin, 2014).

Berdasarkan hasil wawancara yang sudah dilakukan kepada guru kelas IV MI Hayatul Islam Cileat masih terdapat beberapa permasalahan yaitu masih ada siswa yang mendapat nilai ulangan di bawah Kriteria Ketuntasan Minimal (KKM) pada mata pelajaran Fiqih, pelaksanaan pembelajaran di kelas IV MI Hayatul Islam Cileat pada mata pelajaran Fiqih dalam proses kegiatan belajar mengajarnya bersifat monoton yang menyebabkan siswa mengalami kejenuhan, tidak ada variasi dalam pembelajaran yang berakibat pada hasil belajar kognitif siswa yang rendah.

Ketika guru menerapkan model Cooperative Learning tipe Probing Prompting Learning melalui pertanyaan yang dihubungkan dengan permasalahan yang ada pada situasi baru misalnya dengan membeberkan gambar dan sebagainya, akan lebih memudahkan siswa untuk menjawab pertanyaan dari guru. Hal itu dapat membuat siswa 
tertarik untuk terlibat aktif dalam proses pembelajaran. Kemudian proses pembelajaran akan lebih berpusat pada siswa dan hasil belajar kognitif siswa akan meningkat.

Melalui langkah-langkah Cooperative Learning dapat meningkatkan hasil belajar kognitif siswa karena Cooperative Learning melatih siswa untuk belajar mandiri dan mengasah otak siswa dengan diberi kuis-kuis atau soal-soal latihan lainnya. Oleh karena itu, penulis mencoba untuk menerapkan model Cooperative Learning tipe Probing Prompting Learning pada mata pelajaran Fiqih dengan asumsi bahwa dengan diterapkannya model ini proses mata pelajaran Fiqih akan lebih menarik sehingga dapat meningkatkan hasil belajar kognitif siswa dalam mengikuti proses pembelajaran. Penulis memilih kelas IV MI sebagai obyek penelitian dikarenakan kelas tersebut merupakan kelas yang hasil belajar kognitif nya masih rendah dalam mata pelajaran Fiqih.

\section{METODE PENELITIAN}

Pendekatan ini menggunakan pendekatan kualitatif dan kuantitatif. Adapun penelitian ini menggunakan metode Penelitian Tindakan Kelas (PTK) yang di fokuskan pada situasi kelas yang lazim dikenal dengan (Classroom Action Research). Menurut Salahudin (2015) penelitian tindakan kelas adalah penelitian praktis untuk memperbaiki pembelajaran di dalam kelas. Penelitian ini merupakan salah satu upaya guru atau praktisi dalam bentuk berbagai kegiatan yang dilakukan untuk memperbaiki dan meningkatkan mutu pembelajaran dikelas. Penelitian ini merupakan bentuk reflektif berupa tindakan tertentu agar dapat memperbaiki praktik pembelajaran dikelas secara efektif dan efisien serta profesional (Salahudin, 2015).

Melalui penelitian tindakan kelas guru akan lebih banyak memperoleh pengalaman tentang praktik pembelajaran secara efektif, bukan untuk memperoleh ilmu baru dari penelitian tindakan yang dilakukannya. Menurut Aqib (2006) PTK dilaksanakan melalui proses pengkajian berdaur yang terdiri dari 4 tahap, yaitu: (a) Perencanaan, (b) Tindakan, (c) Observasi, (d) Refleksi (Aqib, 2006).

Penelitian tindakan kelas ini akan dilaksanakan selama dua atau tiga siklus sampai hasilnya benar-benar maksimal. Setiap siklus terdiri dari perencanaan, tindakan, observasi, dan refleksi. Jenis penelitian yang dilakukan dalam penelitian ini yang sesuai adalah jenis kualitatif dan kuantitatif. Sumber data pada penelitian adalah peserta didik kelas IV MI Hayatul Islam yang beralamatkan di Cileat Subang, jumlah siswa terdiri dari 22 orang. Sumber data yang digunakan adalah data hasil tes. Jenis tes yang digunakan dalam penelitian ini diperoleh dari hasil penilaian formatif.

Penelitian yang akan dilaksanakan bertujuan untuk melihat perubahan dari hasil belajar yang berdampak dari penerapan model cooperative learning tipe probing prompting learning maka tes yang dilakukan dengan menggunakan penilaian formatif, setiap selesai pembelajaran dilakukannya uji tes untuk keberhasilan pembelajaran. 


\section{HASIL DAN PEMBAHASAN}

Penelitian ini dilakukan dua siklus yang terdiri dari siklus I dan siklus II. Siklus I terdiri dari dua tindakan dan siklus II terdiri dari dua tindakan.

Data awal diperoleh dari hasil belajar kognitif siswa pada mata pelajaran Fiqih di kelas IV masih rendah dan perlu ditingkatkan. Hal ini dapat dilihat pada hasil belajar kognitif siswa setelah pembelajaran tanpa menggunakan model dan media, masih banyak yang belum tuntas.

Hasil belajar kognitif siswa sebelum digunakan model pembelajaran Cooperative Learning tipe Probing Prompting Learning pada kelas IVdi MI Hayatul Islam Cileat masih rendah dari nilai kriteria ketuntasan minimum (KKM) yang ditetapkan disekolah yaitu 70, hal ini dibuktikan dengan hasil belajar kognitif siswa sebelum diterapkannya model pembelajaran Cooperative Learning tipe Probing Prompting Learning. Diketahui rata-rata hasil belajar kognitif siswa dengan nilai 57,72 berada pada kategori "kurang". Ini semua disebabkan karena pembelajaran yang dilakukan masih konvensional dan penggunaan model yang monoton menyebabkan siswa cepat jenuh dan tidak ada variasi dalam pembelajaran yang berakibat pada hasil belajar kognitif yang rendah dan guru yang lebih berperan aktif dibandingkan dengan siswa, dapat dilihat pada table di bawah ini:

Tabel 1. Hasil Belajar Kognitif Siswa Pra Siklus

\begin{tabular}{|c|c|c|c|c|c|c|c|}
\hline \multirow{2}{*}{ No. } & \multirow{2}{*}{ Nama Siswa } & \multicolumn{4}{|c|}{ Nilai Item Soal } & \multirow{2}{*}{ Skor } & \multirow{2}{*}{$\begin{array}{c}\text { Ketuntasan } \\
\text { Individu }\end{array}$} \\
\hline & & 1 & 2 & 3 & 4 & & \\
\hline 1 & $\mathrm{~S} 1$ & 20 & 15 & 25 & 15 & 75 & Tuntas \\
\hline 2 & $\mathrm{~S} 2$ & 20 & 20 & 5 & 5 & 50 & Belum Tuntas \\
\hline 3 & S3 & 15 & 20 & 15 & 5 & 55 & Belum Tuntas \\
\hline 4 & $\mathrm{~S} 4$ & 15 & 5 & 15 & 15 & 50 & Belum Tuntas \\
\hline 5 & S5 & 5 & 20 & 15 & 15 & 55 & Belum Tuntas \\
\hline 6 & S6 & 20 & 5 & 20 & 20 & 65 & Belum Tuntas \\
\hline 7 & S7 & 5 & 20 & 20 & 15 & 60 & Belum Tuntas \\
\hline 8 & S8 & 20 & 20 & 5 & 5 & 50 & Belum Tuntas \\
\hline 9 & S9 & 20 & 20 & 15 & 15 & 70 & Tuntas \\
\hline 10 & S10 & 5 & 5 & 15 & 5 & 30 & Belum Tuntas \\
\hline 11 & S11 & 5 & 20 & 20 & 5 & 50 & Belum Tuntas \\
\hline 12 & S12 & 5 & 25 & 25 & 20 & 75 & Tuntas \\
\hline 13 & S13 & 15 & 15 & 25 & 15 & 70 & Tuntas \\
\hline 14 & S14 & 20 & 20 & 20 & 15 & 75 & Tuntas \\
\hline 15 & S15 & 20 & 20 & 5 & 5 & 50 & Belum Tuntas \\
\hline 16 & S16 & 5 & 20 & 5 & 15 & 45 & Belum Tuntas \\
\hline 17 & S17 & 20 & 20 & 20 & 15 & 75 & Tuntas \\
\hline 18 & S18 & 5 & 20 & 15 & 5 & 45 & Belum Tuntas \\
\hline 19 & S19 & 20 & 20 & 20 & 15 & 75 & Tuntas \\
\hline 20 & S20 & 5 & 20 & 5 & 15 & 45 & Belum Tuntas \\
\hline 21 & $\mathrm{~S} 21$ & 20 & 5 & 15 & 15 & 55 & Belum Tuntas \\
\hline \multirow[t]{4}{*}{22} & $\mathrm{~S} 22$ & 20 & 20 & 5 & 5 & 50 & Belum Tuntas \\
\hline & \multicolumn{5}{|c|}{ Jumlah } & 1270 & \\
\hline & \multicolumn{5}{|c|}{ Rata-rata } & 57,72 & \\
\hline & \multicolumn{5}{|c|}{ Ketuntasan Belajar Klasikal } & $31,81 \%$ & \\
\hline
\end{tabular}


Berdasarkan tabel di atas, dapat diketahui bahwa hasil belajar kognitif siswa pada mata pelajaran Fiqih sebelum menggunakan model Probing Prompting Learning hanya $31,81 \%$ masih banyak yang belum tuntas. Untuk memperoleh nilai rata-rata hasil belajar kognitif siswa di atas yaitu dengan menjumlahkan nilai yang siswa per oleh pada setiap siklusnya, kemudian dibagi dengan jumlah siswa kelas tersebut.

Salah satu cara yang dapat dilakukan untuk meningkatkan hasil belajar kognitif siswa dalam pembelajaran Fiqih ialah dengan menggunakan model Cooperative Learning tipe Probing Prompting Learning. Seperti yang dikemukakan Lie (2002) menyebut Cooperative Learning dengan istilah pembelajaran gotong-royong, yaitu sistem pembelajaran yang memberi kesempatan kepada peserta didik untuk bekerja sama dengan siswa lain dalam tugas-tugas yang terstruktur. Lebih jauh dikatakan, cooperative learning hanya berjalan kalau sudah terbentuk suatu kelompok atau suatu tim yang di dalamnya siswa bekerja secara terarah untuk mencapai tujuan yang sudah ditentukan dengan jumlah anggota kelompok pada umumnya terdiri dari 4-6 orang (Lie, 2002).

Tujuan utama Cooperative Learning dalam penerapan model belajar mengajar adalah agar peserta didik dapat belajar secara berkelompok bersama teman-temannya dengan cara saling menghargai pendapat dan memberikan kesempatan kepada orang lain untuk mengemukakan gagasannya dengan menyampaikan pendapat mereka secara berkelompok (Isjono, 2013).

Probing Prompting Learning adalah pembelajaran dengan cara guru menyajikan serangkaian pertanyaan yang sifatnya menuntun dan menggali sehingga terjadi proses berpikir yang mengaitkan pengetahuan dan pengalaman siswa dengan pengetahuan baru yang sedang dipelajari (Shoimin, 2014). Pembelajaran probing prompting sangat erat kaitannya dengan pertanyaan.Pertanyaan-pertanyaan yang dilontarkan pada saat pembelajaran ini disebut probing question. Probing question adalah pertanyaan yang bersifat menggali untuk mendapatkan jawaban lebih dalam dari siswa yang bermaksud untuk mengembangkan kualitas jawaban, sehingga jawaban berikutnya lebih jelas, akurat dan beralasan (Huda, 2014).

Kemungkinan akan terjadi suasana tegang, tetapi bisa dibiasakan. Untuk mengurangi kondisi tegang, guru hendaknya mengajukan serangkaian pertanyaan di sertai dengan wajah ramah, suara menyejukkan dan nada lembut. Ada canda, senyum dan tertawa sehingga suasana menjadi nyaman, menyenangkan dan ceria. Jangan lupa, jawaban siswa yang salah harus dihargai karena salah adalah ciri bahwa dia sedang belajar dan telah berpartisipasi (Shoimin, 2014).

Pada siklus I proses pembelajaran fiqih dengan menggunakan model Cooperative Learning tipe Probing Prompting Learning dilakukan dalam kelompok kecil. Media pembelajaran ini menggunakan video pembelajaran mengenai materi yang akan dipelajari, agar siswa mudah memahami suatu materi yang dipelajari.

Berdasarkan data yang diperoleh dari hasil observasi aktivitas guru, pada siklus I masih ada beberapa indikator yang belum terlaksana baik dari aktivitas guru ataupun 
aktivitas siswa. Akan tetapi adanya perbaikan dari tindakan pertama ke tindakan selanjutnya maka dari itu aktivitas guru mengalami peningkatan.

Pelaksanaan proses pembelajaran ini dilakukan dikelas IV MI Hayatul Islam Cileat dengan menggunakan model Cooperative Learning tipe Probing Prompting Learning pada mata pelajaran Fiqih dilakukan dua siklus. Setiap siklus terdiri dari dua tindakan.

Hasil observasi aktivitas guru dan aktivitas siswa pada siklus I tindakan I dan tindakan II dapat dilihat pada tabel di bawah ini:

Tabel 1. Hasil Observasi Aktivitas Guru Siklus I Tindakan I

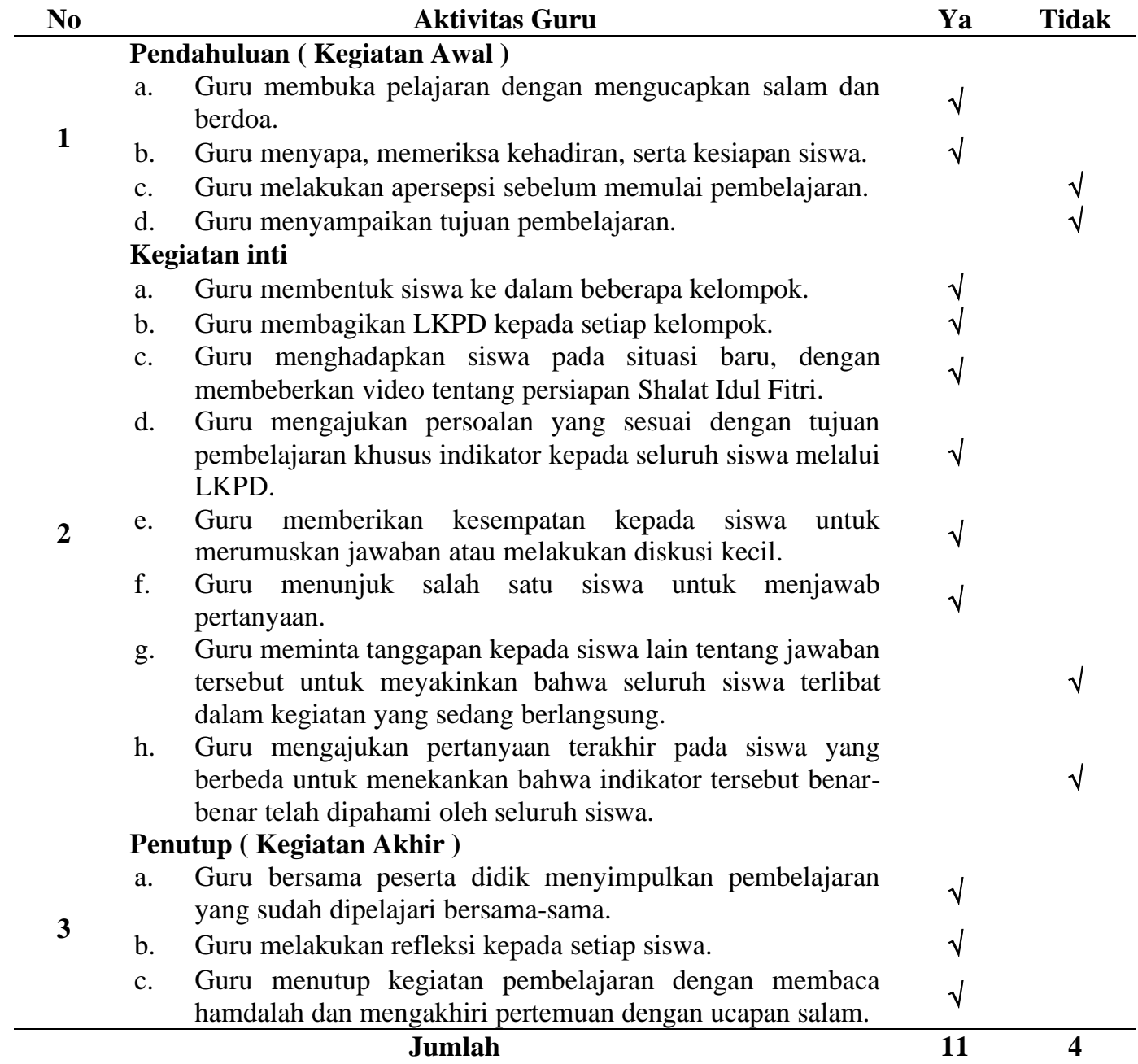

Tabel 2. Hasil Observasi Aktivitas Guru Siklus I Tindakan II

a. Guru membuka pelajaran dengan mengucapkan salam dan berdoa.

1 b. Guru menyapa, memeriksa kehadiran, serta kesiapan siswa.

c. Guru melakukan apersepsi sebelum memulai pembelajaran.

d. Guru menyampaikan tujuan pembelajaran.

$\begin{array}{ll}\sqrt{ } & \\ \sqrt{ } & \\ \sqrt{ } & \\ & \sqrt{ }\end{array}$




\section{Kegiatan inti}

a. Guru membentuk siswa kedalam beberapa kelompok.

b. Guru membagikan LKPD kepada setiap kelompok.

c. Guru menghadapkan siswa pada situasi baru, dengan membeberkan video tentang shalat Idul Fitri.

d. Guru mengajukan persoalan yang sesuai dengan tujuan pembelajaran khusus indikator kepada seluruh siswa melalui LKPD.

2

e. Guru memberikan kesempatan kepada siswa untuk merumuskan jawaban atau melakukan diskusi kecil.

f. Guru menunjuk salah satu siswa untuk menjawab pertanyaan.

g. Guru meminta tanggapan kepada siswa lain tentang jawaban tersebut untuk meyakinkan bahwa seluruh siswa terlibat dalam kegiatan yang sedang berlangsung.

h. Guru mengajukan pertanyaan terakhir pada siswa yang berbeda untuk menekankan bahwa indikator tersebut benarbenar telah dipahami oleh seluruh siswa.

\section{Penutup ( Kegiatan Akhir )}

3

a. Guru bersama peserta didik menyimpulkan pembelajaran yang sudah dipelajari bersama-sama.

b. Guru melakukan refleksi kepada setiap siswa.

c. Guru menutup kegiatan pembelajaran dengan membaca hamdalah dan mengakhiri pertemuan dengan ucapan salam.

\section{Jumlah}

$\sqrt{ }$

$\sqrt{ }$

$\sqrt{ }$

$\sqrt{ }$

$\sqrt{ }$

$\sqrt{ }$

\section{$\sqrt{ }$}

$\sqrt{ }$

$\sqrt{ }$

$\sqrt{ }$

$\sqrt{-1}$

Dari tabel lembar observasi siklus I tindakan I dan tindakan II aktivitas guru dalam proses pembelajaran dengan menggunakan model Cooperative Learning tipe Probing Prompting Learning di kelas IV MI Hayatul Islam Cileat dikatakan terlaksana dengan baik atau tidak dapat dilihat pada tabel di bawah ini:

Tabel 3. Kriteria Keterlaksanaan Aktivitas Pembelajaran

\begin{tabular}{cc} 
Persentase $(\%)$ & Kategori \\
\hline $80 \%-10 \%$ & Baik Sekali \\
$70 \%-79 \%$ & Baik \\
$60 \%-69 \%$ & Cukup \\
$<54 \%$ & Sangat Kurang
\end{tabular}

Tabel 4. Hasil Observasi Aktivitas Siswa Siklus I Tindakan I

\begin{tabular}{clcc} 
No & \multicolumn{1}{c}{ Aktivitas Siswa } & Ya & Tidak \\
\hline 1 & Siswa menjawab salam guru dan berdoa. & $\sqrt{ }$ & \\
2 & Siswa memperhatikan guru ketika sedang memeriksa kehadiran, & $\sqrt{ }$ & \\
3 & kerapian dan kesiapan siswa. & Siswa mengikuti instruksi guru. & $\sqrt{ }$ \\
4 & Siswa memperhatikan dengan seksama apa yang disampaikan oleh & & $\sqrt{ }$ \\
5 & guru. & $\sqrt{ }$ & \\
6 & Siswa membentuk kelompok. & $\sqrt{ }$ & \\
7 & Siswa memperhatikan video yang diperlihatkan oleh guru. & $\sqrt{ }$ & \\
8 & Siswa menjawab persoalan yang dipertanyakan oleh guru. & $\sqrt{ }$ & \\
9 & Siswa merumuskan jawaban atau melakukan diskusi kecil. & $\sqrt{ }$ & \\
10 & Salah satu siswa menjawab pertanyaan. & $\sqrt{ }$ & \\
11 & Siswa lain memberikan tanggapan tentang jawaban tersebut. & & $\sqrt{ }$
\end{tabular}


Siswa menjawab pertanyaan terakhir yang berbeda dari guru.

13 Siswa menyimpulkan pembelajaran yang sudah dilaksanakan.

14 Siswa mengerjakan tugas yang diberikan oleh guru.

15 Siswa menjawab salam dan berdoa

Jumlah

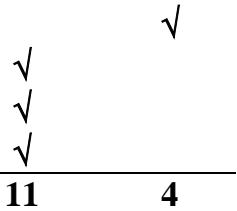

Tabel 5. Hasil Observasi Aktivitas Siswa Siklus I Tindakan II

\begin{tabular}{clcc} 
No & \multicolumn{1}{c}{ Aktivitas Siswa } & Ya & Tidak \\
\hline 1 & Siswa menjawab salam guru dan berdoa. & $\sqrt{ }$ & \\
2 & $\begin{array}{l}\text { Siswa memperhatikan guru ketika sedang memeriksa kehadiran, } \\
\text { kerapian dan kesiapan siswa. }\end{array}$ & $\sqrt{ }$ & \\
3 & Siswa mengikuti instruksi guru. & $\sqrt{ }$ & \\
4 & Siswa memperhatikan dengan seksama apa yang disampaikan oleh & & $\sqrt{ }$ \\
5 & guru. & Siswa membentuk kelompok. & $\sqrt{ }$ \\
6 & Setiap kelompok mendapatkan LKPD dari guru. & $\sqrt{ }$ \\
7 & Siswa memperhatikan video yang diperlihatkan oleh guru. & $\sqrt{ }$ \\
8 & Siswa menjawab persoalan yang dipertanyakan oleh guru. & $\sqrt{ }$ \\
9 & Siswa merumuskan jawaban atau melakukan diskusi kecil. & $\sqrt{ }$ \\
10 & Salah satu siswa menjawab pertanyaan. & $\sqrt{ }$ \\
11 & Siswa lain memberikan tanggapan tentang jawaban tersebut. & $\sqrt{ }$ \\
12 & Siswa menjawab pertanyaan terakhir yang berbeda dari guru. & $\sqrt{ }$ \\
13 & Siswa menyimpulkan pembelajaran yang sudah dilaksanakan. & $\sqrt{ }$ \\
14 & Siswa mengerjakan tugas yang diberikan oleh guru. & $\sqrt{ }$ \\
15 & Siswa menjawab salam dan berdoa & $\mathbf{1 3}$ & $\mathbf{2}$
\end{tabular}

Dari tabel lembar observasi siklus I tindakan I dan tindakan II aktivitas siswa dalam proses pembelajaran dengan menggunakan model Cooperative Learning tipe Probing Prompting Learning di kelas IV MI Hayatul Islam Cileat dikatakan terlaksana dengan baik atau tidak dapat dilihat pada tabel di bawah ini:

Tabel 6. Kriteria Keterlaksanaan Aktivitas Pembelajaran

\begin{tabular}{cc} 
Persentase $(\%)$ & Kategori \\
\hline $80 \%-10 \%$ & Baik Sekali \\
$70 \%-79 \%$ & Baik \\
$60 \%-69 \%$ & Cukup \\
$<54 \%$ & Sangat Kurang
\end{tabular}

Hasil observasi aktivitas guru dan aktivitas siswa pada siklus II tindakan I dan tindakan II dapat dilihat pada tabel di bawah ini:

Tabel 8. Hasil Observasi Aktivitas Guru Siklus II Tindakan I

\begin{tabular}{|c|c|c|c|}
\hline No & Aktivitas Guru & Ya & Tidak \\
\hline \multicolumn{4}{|c|}{ Pendahuluan ( Kegiatan Awal ) } \\
\hline & $\begin{array}{l}\text { a. Guru membuka pelajaran dengan mengucapkan salam dan } \\
\text { berdoa. }\end{array}$ & $\sqrt{ }$ & \\
\hline $\mathbf{I}$ & b. Guru menyapa, memeriksa kehadiran, serta kesiapan siswa. & $\sqrt{ }$ & \\
\hline & $\begin{array}{l}\text { c. Guru melakukan apersepsi sebelum memulai pembelajaran. } \\
\text { d. Guru menyampaikan tujuan pembelajaran. }\end{array}$ & $\sqrt{ }$ & $\sqrt{ }$ \\
\hline 2 & Kegiatan inti & & \\
\hline
\end{tabular}


a. Guru membentuk siswa ke dalam beberapa kelompok.

b. Guru membagikan LKPD kepada setiap kelompok.

c. Guru menghadapkan siswa pada situasi baru, dengan membeberkan video tentang persiapan Shalat Jumat.

d. Guru mengajukan persoalan yang sesuai dengan tujuan pembelajaran khusus indikator kepada seluruh siswa melalui LKPD.

e. Guru memberikan kesempatan kepada siswa untuk $\sqrt{ }$ merumuskan jawaban atau melakukan diskusi kecil.

f. Guru menunjuk salah satu siswa untuk menjawab pertanyaan.

g. Guru meminta tanggapan kepada siswa lain tentang jawaban tersebut untuk meyakinkan bahwa seluruh siswa terlibat dalam kegiatan yang sedang berlangsung.

h. Guru mengajukan pertanyaan terakhir pada siswa yang berbeda untuk menekankan bahwa indikator tersebut benarbenar telah dipahami oleh seluruh siswa.

Penutup ( Kegiatan Akhir )

a. Guru bersama peserta didik menyimpulkan pembelajaran yang sudah dipelajari bersama-sama.

b. Guru melakukan refleksi kepada setiap siswa.

c. Guru menutup kegiatan pembelajaran dengan membaca hamdalah dan mengakhiri pertemuan dengan ucapan salam.

Tabel 9. Hasil Observasi Aktivitas Guru Siklus II Tindakan II

\section{Pendahuluan ( Kegiatan Awal )}

a. Guru membuka pelajaran dengan mengucapkan salam dan berdoa.

b. Guru menyapa, memeriksa kehadiran, serta kesiapan siswa.

c. Guru melakukan apersepsi sebelum memulai pembelajaran.

d. Guru menyampaikan tujuan pembelajaran.

Kegiatan inti

a. Guru membentuk siswa ke dalam beberapa kelompok.

b. Guru membagikan LKPD kepada setiap kelompok.

c. Guru menghadapkan siswa pada situasi baru, dengan membeberkan video tentang persiapan Shalat Jumat.

$\sqrt{ }$

$\sqrt{ }$

$\sqrt{ }$

$\sqrt{ }$

$\sqrt{ }$

$\sqrt{ }$

$\sqrt{ }$

d. Guru mengajukan persoalan yang sesuai dengan tujuan pembelajaran khusus indikator kepada seluruh siswa melalui $\quad \sqrt{ }$ LKPD.

e. Guru memberikan kesempatan kepada siswa untuk merumuskan jawaban atau melakukan diskusi kecil.

f. Guru menunjuk salah satu siswa untuk menjawab pertanyaan.

g. Guru meminta tanggapan kepada siswa lain tentang jawaban tersebut untuk meyakinkan bahwa seluruh siswa terlibat dalam kegiatan yang sedang berlangsung.

h. Guru mengajukan pertanyaan terakhir pada siswa yang berbeda untuk menekankan bahwa indikator tersebut benarbenar telah dipahami oleh seluruh siswa.

\section{Penutup ( Kegiatan Akhir )}

a. Guru bersama peserta didik menyimpulkan pembelajaran yang sudah dipelajari bersama-sama.

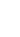


b. Guru melakukan refleksi kepada setiap siswa.

c. Guru menutup kegiatan pembelajaran dengan membaca hamdalah dan mengakhiri pertemuan dengan ucapan salam.

Dari tabel lembar observasi siklus II tindakan I dan tindakan II aktivitas guru dalam proses pembelajaran dengan menggunakan model Cooperative Learning tipe Probing Prompting Learning di kelas IV MI Hayatul Islam Cileat dikatakan terlaksana dengan baik atau tidak dapat dilihat pada tabel dibawah ini:

Tabel 10. Kriteria Keterlaksanaan Aktivitas Pembelajaran

\begin{tabular}{cc} 
Persentase $(\boldsymbol{\%})$ & Kategori \\
\hline $80-100 \%$ & Baik Sekali \\
$70-79 \%$ & Baik \\
$60-69 \%$ & Cukup \\
$<50 \%$ & Kurang
\end{tabular}

Tabel 11. Hasil Observasi Aktivitas Siswa Siklus II Tindakan I

\begin{tabular}{clcc}
\multicolumn{1}{c}{ Aktivitas Siswa } & Ya & Tidak \\
\hline 1 & Siswa menjawab salam guru dan berdoa. & $\sqrt{ }$ & \\
2 & $\begin{array}{l}\text { Siswa memperhatikan guru ketika sedang memeriksa kehadiran, } \\
\text { kerapian dan kesiapan siswa. }\end{array}$ & $\sqrt{ }$ \\
3 & Siswa mengikuti instruksi guru. & $\sqrt{ }$ & $\sqrt{ }$ \\
4 & Siswa memperhatikan dengan seksama apa yang disampaikan oleh & & \\
5 & guru. & $\sqrt{ }$ \\
6 & Siswa membentuk kelompok. & $\sqrt{ }$ \\
7 & Siswa memperhatikan video yang diperlihatkan oleh guru. & $\sqrt{ }$ \\
8 & Siswa menjawab persoalan yang dipertanyakan oleh guru. & $\sqrt{ }$ \\
9 & Siswa merumuskan jawaban atau melakukan diskusi kecil. & $\sqrt{ }$ \\
10 & Salah satu siswa menjawab pertanyaan. & $\sqrt{ }$ \\
11 & Siswa lain memberikan tanggapan tentang jawaban tersebut. & $\sqrt{ }$ \\
12 & Siswa menjawab pertanyaan terakhir yang berbeda dari guru. & $\sqrt{ }$ \\
13 & Siswa menyimpulkan pembelajaran yang sudah dilaksanakan. & $\sqrt{ }$ \\
14 & Siswa mengerjakan tugas yang diberikan oleh guru. & $\sqrt{ }$ \\
15 & Siswa menjawab salam dan berdoa & $\mathbf{1 3}$
\end{tabular}

Tabel 12. Observasi Aktivitas Siswa Siklus II Tindakan II

\begin{tabular}{clcc}
\multicolumn{1}{c}{ Aktivitas Siswa } & Ya & Tidak \\
\hline 1 & $\begin{array}{l}\text { Siswa menjawab salam guru dan berdoa. } \\
2\end{array}$ & $\sqrt{ }$ \\
& $\begin{array}{l}\text { Siswa memperhatikan guru ketika sedang memeriksa kehadiran, } \\
\text { kerapian dan kesiapan siswa. }\end{array}$ & $\sqrt{ }$ \\
3 & $\begin{array}{l}\text { Siswa mengikuti instruksi guru. } \\
4\end{array}$ & Siswa memperhatikan dengan seksama apa yang disampaikan oleh & $\sqrt{ }$ \\
5 & guru. & $\sqrt{ }$ \\
6 & Siswa membentuk kelompok. & $\sqrt{ }$ \\
7 & Siswa melompok mendapatkan LKPD dari guru. & $\sqrt{ }$ \\
8 & Siswa menjawab persoalan yang dipertanyakan oleh guru. & $\sqrt{ }$ \\
9 & Siswa merumuskan jawaban atau melakukan diskusi kecil. & $\sqrt{ }$
\end{tabular}


Anas Salahudin, Hariman Surya Siregar, Annisa Nur'azizah

Penerapan Model Cooperative Learning Tipe Probing Prompting

10 Salah satu siswa menjawab pertanyaan.

11 Siswa lain memberikan tanggapan tentang jawaban tersebut.

12 Siswa menjawab pertanyaan terakhir yang berbeda dari guru.

13 Siswa menyimpulkan pembelajaran yang sudah dilaksanakan.

14 Siswa mengerjakan tugas yang diberikan oleh guru.

15 Siswa menjawab salam dan berdoa

Jumlah

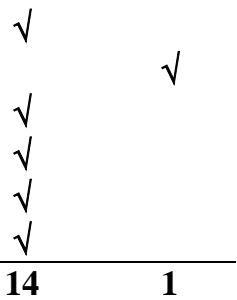

Dari tabel lembar observasi siklus II tindakan I dan tindakan II aktivitas siswa dalam proses pembelajaran dengan menggunakan model Cooperative Learning tipe Probing Prompting Learning di kelas IV MI Hayatul Islam Cileat dikatakan terlaksana dengan baik atau tidak dapat dilihat pada tabel di bawah ini:

Tabel 13. Kriteria Keterlaksanaan Aktivitas Pembelajaran

\begin{tabular}{cc} 
Persentase $(\%)$ & Kategori \\
\hline $80 \%-10 \%$ & Baik Sekali \\
$70 \%-79 \%$ & Baik \\
$60 \%-69 \%$ & Cukup \\
$<54 \%$ & Sangat Kurang
\end{tabular}

\section{a. Hasil Belajar Siswa Siklus I}

Tabel 14. Hasil Belajar Kognitif Siswa Siklus I

\begin{tabular}{cccccc} 
No. & Nama & $\begin{array}{c}\text { Perolehan Nilai } \\
\text { Siklus I } \\
\text { Siswa }\end{array}$ & $\begin{array}{c}\text { Siklus I } \\
\text { Tindakan II }\end{array}$ & $\begin{array}{c}\text { Rata-rata } \\
\text { (Nilai Siklus I) }\end{array}$ & $\begin{array}{c}\text { Ketuntasan } \\
\text { Individu }\end{array}$ \\
\hline 1 & S1 & 80 & 85 & 82,5 & Tuntas \\
2 & S2 & 70 & 70 & 70 & Tuntas \\
3 & S3 & 60 & 65 & 62,5 & Belum Tuntas \\
4 & S4 & 65 & 70 & 67,5 & Belum Tuntas \\
5 & S5 & 75 & 75 & 75 & Tuntas \\
6 & S6 & 75 & 80 & 77,5 & Tuntas \\
7 & S7 & 70 & 65 & 70 & Tuntas \\
8 & S6 & 60 & 80 & 62,5 & Belum Tuntas \\
9 & S9 & 75 & 60 & 77,5 & Tuntas \\
10 & S10 & 50 & 80 & 55 & Belum Tuntas \\
11 & S11 & 65 & 75 & 67,5 & Belum Tuntas \\
12 & S12 & 80 & 80 & 82,5 & Tuntas \\
13 & S13 & 75 & 65 & 75 & Tuntas \\
14 & S14 & 80 & 60 & 80 & Tuntas \\
15 & S15 & 55 & 80 & 60 & Belum Tuntas \\
16 & S16 & 50 & 70 & 55 & Belum Tuntas \\
17 & S17 & 80 & 80 & 80 & Tuntas \\
18 & S18 & 60 & 70 & 65 & Belum Tuntas \\
19 & S19 & 80 & 75 & 80 & Tuntas \\
20 & S20 & 60 & 70 & 65 & Belum Tuntas \\
21 & S21 & 65 & & 70 & Tuntas \\
22 & S22 & 65 & Jumlah & 67,5 & Belum Tuntas \\
\hline & & Rata-rata Kelas & & & $\mathbf{7 0 , 3 4}$ \\
& & Ketuntasan Klasikal & $54,54 \%$ &
\end{tabular}


Tabel 15. Presentase Hasil Belajar Siswa

\begin{tabular}{c} 
Presentase Hasil Belajar \\
\hline$<70 \%$ \\
$70-79 \%$ \\
$80-89 \%$ \\
$90-100 \%$
\end{tabular}

Kategori
Kurang
Cukup
Tinggi
Tinggi Sekali

Dari perhitungan rata-rata, pada siklus I dapat disimpulkan bahwa perolehan ratarata kelas sebesar 70,34 sehingga termasuk ke dalam kriteria cukup, sedangkan ketuntasan klasikal sebesar 54,54\% dari jumlah siswa berjumlah 22 orang dan dapat dikatakan dalam kriteria kurang.

\section{b. Hasil Belajar Siswa Siklus II}

Setelah dilaksanakan proses belajar mengajar dengan menggunakan model Cooperative Learning tipe Probing Prompting Learning pada mata pelajaran Fiqih untuk meningkatkan hasil belajar kognitif siswa di siklus II sebagai tindak lanjut dari siklus I, diperoleh hasil belajar sebagai berikut:

Tabel 16. Hasil Belajar Kognitif Siswa Siklus II

\begin{tabular}{|c|c|c|c|c|c|}
\hline \multirow[b]{2}{*}{ No. } & \multirow{2}{*}{$\begin{array}{l}\text { Nama } \\
\text { Siswa }\end{array}$} & \multicolumn{2}{|c|}{ Perolehan Nilai } & \multirow{2}{*}{$\begin{array}{c}\text { Rata-rata (Nilai } \\
\text { Siklus II) }\end{array}$} & \multirow{2}{*}{$\begin{array}{c}\text { Ketuntasan } \\
\text { Individu }\end{array}$} \\
\hline & & $\begin{array}{c}\text { Siklus II } \\
\text { Tindakan I }\end{array}$ & $\begin{array}{c}\text { Siklus II } \\
\text { Tindakan II }\end{array}$ & & \\
\hline 1 & S1 & 90 & 95 & 92,5 & Tuntas \\
\hline 2 & S2 & 75 & 85 & 80 & Tuntas \\
\hline 3 & S3 & 80 & 85 & 82,5 & Tuntas \\
\hline 4 & $\mathrm{~S} 4$ & 75 & 80 & 77,5 & Tuntas \\
\hline 5 & S5 & 80 & 85 & 82,5 & Tuntas \\
\hline 6 & S6 & 85 & 90 & 87,5 & Tuntas \\
\hline 7 & S7 & 75 & 85 & 80 & Tuntas \\
\hline 8 & S8 & 75 & 85 & 80 & Tuntas \\
\hline 9 & S9 & 75 & 95 & 85 & Tuntas \\
\hline 10 & $\mathrm{~S} 10$ & 85 & 80 & 82,5 & Tuntas \\
\hline 11 & S11 & 65 & 85 & 75 & Tuntas \\
\hline 12 & $\mathrm{~S} 12$ & 80 & 90 & 85 & Tuntas \\
\hline 13 & S13 & 85 & 85 & 85 & Tuntas \\
\hline 14 & S14 & 80 & 90 & 85 & Tuntas \\
\hline 15 & S15 & 0 & 80 & 40 & Belum Tuntas \\
\hline 16 & S16 & 70 & 85 & 77,5 & Tuntas \\
\hline 17 & S17 & 65 & 90 & 77,5 & Tuntas \\
\hline 18 & S18 & 85 & 80 & 82,5 & Tuntas \\
\hline 19 & S19 & 75 & 90 & 82,5 & Tuntas \\
\hline 20 & S20 & 85 & 85 & 85 & Tuntas \\
\hline 21 & S21 & 80 & 85 & 82,5 & Tuntas \\
\hline 22 & $\mathrm{~S} 22$ & 80 & 80 & 80 & Tuntas \\
\hline & & Jumlah & & & \\
\hline & & ata-rata Kela & & 82 & \\
\hline & & intasan Klas & & $\mathbf{9 5}$, & \\
\hline
\end{tabular}

Berdasarkan data di atas, model Cooperative Learning tipe Probing Prompting Learning ternyata mampu menarik perhatian siswa sehingga timbul motivasi untuk aktif dalam pembelajaran. Hal tersebut sejalan dengan pendapat Huda (2014).Proses probing 
dapat mengaktifkan siswa dalam belajar yang penuh tantangan, sebab ia menuntut konsentrasi dan keaktifan. Selanjutnya, perhatian siswa terhadap pembelajaran yang sedang dipelajari cenderung lebih terjaga karena siswa selalu mempersiapkan jawaban, sebab mereka harus selalu siap jika tiba-tiba ditunjuk oleh guru. Sehingga dengan menggunakan model Probing Prompting Learning setiap siswa mau tidak mau harus berpartisipasi aktif, siswa tidak bisa menghindar dari proses pembelajaran, setiap saat ia bisa saja dilibatkan dalam proses tanya jawab setalah siswa selesai berdiskusi dengan kelompoknya (Huda, 2014).

Dengan demikian, dapat diketahui bahwa dengan menggunakan model Cooperative Learning tipe Probing Prompting Learning dapat meningkatkan hasil belajar kognitif siswa pada mata pelajaran Fiqih kelas IV MI Hayatul Islam Cileat tahun ajaran 2018/2019, hal ini karena dengan menggunakan model Cooperative Learning tipe Probing Prompting Learning siswa dapat mendorong/memotivasi siswa untuk belajar lebih aktif, dapat menggali potensi siswa dalam menjawab pertanyaan serta siswa tertantang untuk menjawab pertanyaan yang dilontarkan oleh guru, terutama jika guru memberikan penghargaan terhadap siswa yang dapat menjawab pertanyaan baik dengan pujian maupun dengan penilaian.

\section{KESIMPULAN DAN SARAN}

Berdasarkan hasil pembahasan dapat disimpulkan bahwa hasil belajar kognitif siswa pada mata pelajaran Fiqih tentang Shalat Idain dan Shalat Jumat setelah diterapkan model Cooperative Learning tipe Probing Prompting Learning mengalami peningkatan pada setiap siklus. Hal tersebut menunjukan bahwa hasil belajar siswa pada mata pelajaran Fiqih kelas IV MI Hayatul Islam Cileat dinyatakan meningkat. Dengan demikian, penerapan model Cooperative Learning tipe Probing Prompting Learning dapat meningkatkan hasil belajar kognitif siswa pada mata pelajaran Fiqih.

Selanjutnya ada beberapa saran yang akan peneliti sampaikan yaitu, Pembelajaran dengan menggunakan model Cooperative Learning tipe Probing Prompting Learning dapat meningkatkan hasil belajar kognitif siswa. Sehingga model ini menjadi alternatif yang dapat digunakan oleh guru, dalam proses pembelajaran agar lebih efektif. selain itu, untuk mengukur keberhasilan pembelajaran Fiqih tentang Shalat Idan dan Shalat Jum'at, maka setiap selesai proses pembelajaran harus dilakukan evaluasi kepada setiap siswa. Hal tersebut guna mengetahui pemahaman siswa terhadap materi yang disampaikan.

\section{REFERENSI}

Aqib, Zainal. (2006). Penelitian Tindakan Kelas. Bandung: CV. Rama Widya.

Huda, Miftahul. (2014). Model-Model Pengajaran dan Pembelajaran. Yogyakarta: Pustaka Belajar.

Isjono. (2013). Cooperative Learning Efektifitas Pembelajaran Kelompok. Bandung: Alfabeta. 
Lie, Anita. (2002). Cooperative Learning Mempraktikan Cooperative Learning di ruangruang kelas. Jakarta: Grasindo.

Salahudin, Anas. (2015). Penelitian Tindakan Kelas. Bandung: CV. Pustaka Setia.

Shoimin, Aris. (2014). 68 Model Pembelajaran Inovatif dalam Kurikulum 2013. Yogyakarta: Ar-Ruzz Media.

Undang-Undang Nomor 20 Tahun 2003 tentang Sistem Pendidikan Nasional. 